\title{
Analiza wiedzy studentów PWSZ we Włocławku na temat udzielania pierwszej pomocy
}

\author{
Analysis of the knowledge of PWSZ students in Włocławek about \\ providing first pre - medical help
}

MAGDALENA ZAWIDZKA , BEATA HAOR ${ }^{2}$, KLAUDIA DASZUTA ${ }^{2,3}$

1Studenckie Koło Naukowe Nauk o Zdrowiu, Instytut Nauk o Zdrowiu Państwowej Uczelni Zawodowej we Włocławku, opiekun Koła: dr Beata Haor

2 Instytut Nauk o Zdrowiu Państwowej Uczelni Zawodowej we Włocławku

3 Wojewódzki Szpital Specjalistyczny we Włocławku im. bł. ks. J. Popiełuszki, Oddział Anestezjologii i Intensywnej Terapii

DOI: http://dx.doi.org/10.21784/IwP.2019.013

ISSN:2451-1846

\section{Streszczenie:}

Wstęp. Pierwsza pomoc to proste czynności wykonywane natychmiast przez pierwszych świadków zdarzenia w sytuacji nagłego zagrożenia zdrowia i życia ludzkiego, zanim przybędą wykwalifikowane służby ratownicze. Do udzielania pierwszej pomocy zobligowany jest każdy obywatel.

Cel. Celem badań była analiza wiedzy studentów PWSZ we Włocławku na temat udzielania pierwszej pomocy

Materiał i metody. Badania przeprowadzono wśród 183 studentów PWSZ we Włocławku. Wykorzystano metodę sondażu diagnostycznego, technikę ankietowania oraz autorski kwestionariusz ankiety.

Wyniki. Studenci dysponują zróżnicowaną wiedzą na temat aspektów udzielania pierwszej pomocy. Większość ankietowanych potwierdziło, że każdy obywatel ma obowiązek podejmować działania służące udzielaniu pomocy. Niemniej jednak znaczny odsetek badanych nie podjąłby takich czynności.

Wnioski. Studenci prezentują umiarkowany poziom wiedzy w zakresie udzielania pierwszej pomocy. Niezbędne są systematyczne działania 
edukacyjne w zakresie ich przygotowania do świadomego, odpowiedzialnego udziału w ratowaniu życia drugiego człowieka.

Słowa kluczowe: pierwsza pomoc, wiedza, BLS

\begin{abstract}
:
Introduction. First aid is simply activities taken immediately by the first witnesses of the event in the situation of a sudden threat to health and human life before the arrival of qualified emergency services. Every citizen is obliged to provide first aid.
\end{abstract}

The aim. The aim of the research was to analyze the knowledge about first aid of PWSZ students in Włocławek.

Material and methods. The research was conducted among 185 students of PWSZ in Włocławek. The method of diagnostic survey, questionnaire and author's questionnaire were used.

Results. Students have moderate knowledge about the aspects of first aid. Most of the respondents confirmed that every citizen is obliged to take actions to provide help. Nevertheless, a significant percentage of respondents would not undertake such activities.

Conclusions. Students present a moderate level of knowledge in the field of first aid. Systematic educational activities are necessary in the field of their preparation for conscious, responsible participation in saving lives of other people.

Keywords. First aid, knowledge, BLS

\title{
Wstęp
}

Pierwszą pomoc określamy jako zespół czynnościach wykonywanych w celu ratowania osoby znajdującej się w nagłym stanie zagrożenia życia, przez osobę będąca w miejscy zdarzenia przy użyciu wyrobów medycznych, a także produktów leczniczych wydawanych bez pisemnego zlecenia lekarskiego. Na terytorium Rzeczpospolitej Polskiej każdy obywatel jest zobligowany do udzielenia pierwszej pomocy każdemu, kto jej potrzebuje. Obowiązek ten zapisany jest w Ustawie o Państwowym Ratownictwie 
Medycznym z dnia 8 września 2006r. raz w art. 162 Kodeksu Karnego $[1,2,3,4]$.

Każdy człowiek powinien posiadać umiejętność udzielania pierwszej pomocy. Dzięki znajomości tych zasad, zwiększa się szansa na przeżycie osoby poszkodowanej z uwagi na udzielane jej wsparcie do momentu przyjazdu wykwalifikowanych służb. Opanowanie podstawowych zabiegów resuscytacyjnych BLS (Basic Life Suport) czyli bezprzyrządowego utrzymania drożności dróg oddechowych oraz podtrzymania oddychania i krążenia, daje możliwość sprawnego działania w udzielaniu pierwszej pomocy [5].

Niezwykle ważnym elementem udzielania pierwszej pomocy jest tzw. łańcuch przeżycia. Składa się z czterech ogniw, które wskazują kolejne etapy $\mathrm{w}$ przypadku NZK (nagłego zatrzymania krążenia) oraz wykorzystania czasu przed przystąpieniem do medycznych czynności ratunkowych. Pierwsze ogniwo dotyczy rozpoznania stanu zagrożenia życia oraz wezwania profesjonalnej pomocy, a także upewnienia się, że podjęcie czynności ratujących życie jest możliwe i nie zagraża życiu osoby udzielającej pomocy. Drugie ogniwo informuje o wczesnym rozpoczęciu RKO (resuscytacji krążeniowo - oddechowej), dzięki czemu zwiększa się szanse na przeżycie do momentu przyjazdu zespołu ratownictwa medycznego. Trzecim ogniwem jest możliwie jak najszybsza defibrylacja. Ostatnim ogniwem jest opieka poresuscytacyjna, której zadaniem jest utrzymanie prawidłowych funkcji mózgu oraz serca [5].

\section{Cel pracy}

Celem badań była analiza wiedzy studentów Państwowej Wyższej Szkoły Zawodowej we Włocławku na temat udzielania pierwszej pomocy. 


\section{Materiał i metody}

Badania przeprowadzono wśród 185 studentów PWSZ we Włocławku. Wykorzystano metodę sondażu diagnostycznego, technikę ankietowania oraz autorski kwestionariusz ankiety.

\section{Wyniki}

Grupę badaną stanowią studenci kierunków: pielęgniarstwo $(20,75 \%)$, pedagogika $(13,145)$, mechanika i budowa maszyn (10,38\%), inżynieria zarządzania (10,38\%), administracja $(10,92 \%)$, finanse i rachunkowość $(11,47 \%)$, informatyka $(9,28 \%)$ oraz nowe media i e - biznes (6,65\%) i filologia angielska (7,65\%). Większość badanych stanowiły kobiety(64\%) oraz mieszkańcy miasta $(61,60 \%)$. Średnia wieku respondentów wynosiła 29,33. Ponad połowa ankietowanych to panny i kawalerowie (53\%), natomiast 1,6\% respondentów stanowili wdowy i wdowcy. Poniżej zaprezentowano wyniki badań własnych.

Tabela 1 przedstawia procentowy rozkład odpowiedzi respondentów na pytanie dotyczące subiektywnej opinii ankietowanych nt. wiedzy z zakresu udzielania pierwszej pomocy.

Tab.1. Opinia badanych nt. swojej wiedzy z zakresu udzielania pierwszej pomocy.

\begin{tabular}{|c|c|c|}
\hline & \multicolumn{2}{|c|}{ Odpowiedzi } \\
\cline { 2 - 3 } $\begin{array}{c}\text { 1.Jak ocenia Pan/Pani swoją wiedzę z } \\
\text { zakresu udzielania pierwszej pomocy? }\end{array}$ & $\%$ & $\mathrm{~N}$ \\
\hline Bardzo dobrze & & 24 \\
\hline Dobrze & $12,9 \%$ & 53 \\
\hline Umiarkowanie & $28,5 \%$ & 71 \\
\hline Niezbyt dobrze & $38,2 \%$ & 29 \\
\hline Źle & $15,6 \%$ & 9 \\
\hline
\end{tabular}

Źródło: Opracowanie własne. 
Jak wynika z tabeli 1 swoją wiedzę nt. udzielania pierwszej pomocy bardzo dobrze ocenia zaledwie $12,9 \%$ badanych, a dobrze $28,5 \%$. Około 38\% (38,2\%) respondentów uważa, że jego wiedza w powyższym zakresie jest na poziomie umiarkowanym. Natomiast około $16 \%$ ankietowanych $(15,6 \%)$ ocenia swoją wiedzę niezbyt dobrze, zaś 4,8\% źle.

Tabela 2 przedstawia procentowy rozkład odpowiedzi na pytanie dotyczące źródła informacji nt. udzielania pierwszej pomocy.

Tab.2. Opinia respondentów nt. źródła informacji nt. udzielania pierwszej pomocy.

\begin{tabular}{|c|c|c|}
\hline & \multicolumn{2}{|c|}{ Odpowiedzi } \\
\cline { 2 - 3 } $\begin{array}{c}\text { 2. Skąd czerpie Pan/Pani wiedzę nt. } \\
\text { udzielania pierwszej pomocy? }\end{array}$ & $\%$ & $\mathrm{~N}$ \\
\hline $\begin{array}{c}\text { Środki masowego przekazu (Internet,radio, } \\
\text { TV, gazety) }\end{array}$ & $12,9 \%$ & 26 \\
\hline Książki ( podręczniki, poradniki) & $30,3 \%$ & 61 \\
\hline Z zajęć, kursów, szkoleń & $38,3 \%$ & 77 \\
\hline Własnego doświadczenia & $12,9 \%$ & 26 \\
\hline Od innych osób & $5,5 \%$ & 11 \\
\hline
\end{tabular}

Źródło: Opracowanie własne.

Jak wynika z tabeli 2 około 38\% ankietowanych (38,3\%) deklaruje, że swoją wiedzę nt. pierwszej pomocy czerpie z zajęć, kursów i szkoleń, nieco mniej (30,3\%) badanych korzysta z książek. Środki masowego przekazu oraz własne doświadczenia wykorzystuje blisko 13\% respondentów $(12,9)$. Natomiast 5,5\% ankietowanych wiedzę o udzielaniu pierwszej pomocy uzyskuje od innych osób. 
Tabela 3 obrazuje procentowy rozkład odpowiedzi na pytanie dotyczące ewentualnej możliwości podjęcia się udzielenia pierwszej pomocy=

Tab.3. Opinia respondentów nt. podjęcia się udzielania pierwszej pomocy.

\begin{tabular}{|c|c|c|}
\hline \multirow{2}{*}{$\begin{array}{c}\text { 3. Czy podjąłby/podjęłaby się Pani/Pan } \\
\text { udzielenia pierwszej pomocy? }\end{array}$} & \multicolumn{2}{|c|}{ Odpowiedzi } \\
\cline { 2 - 3 } & $\%$ & $\mathrm{~N}$ \\
\hline Tak & $49,2 \%$ & 91 \\
\hline Nie & $29,2 \%$ & 54 \\
\hline Nie wiem & $21,6 \%$ & 40 \\
\hline
\end{tabular}

Źródło: Opracowanie własne.

Jak wynika z tabeli 3 około 50\% badanych (49,2\%) deklaruje, że w razie konieczności jest w stanie podjąć się udzielenia pierwszej pomocy.- Natomiast $29,2 \%$ ankietowanych nie jest na to gotowa. Znaczny odsetek respondentów $(21,6 \%)$ nie potrafi jednoznacznie stwierdzić, czy podejmie się udzielenia pierwszej pomocy.

W tabeli 4 przedstawiono procentowy rozkład odpowiedzi na pytanie dotyczące momentu rozpoczęcia resuscytacji oddechowo - krążeniowej.

Tab.4. Opinia respondentów nt. czasu rozpoczęcia RKO.

\begin{tabular}{|c|c|c|}
\hline \multirow{2}{*}{$\begin{array}{c}\text { 4. Czy wie Pan/Pani kiedy należy rozpocząc } \\
\text { resuscytację krążeniowo-oddechową } \\
\text { (uciskanie klatki piersiowej i oddechy } \\
\text { ratunkowe) u osoby poszkodowanej? }\end{array}$} & \multicolumn{2}{|c|}{ Odpowiedzi } \\
\cline { 2 - 3 } & $\%$ & $\mathrm{~N}$ \\
\hline Gdy jest nieprzytomna i prawidłowo oddycha & $20,5 \%$ & 38 \\
\hline $\begin{array}{c}\text { Gdy jest nieprzytomna i nie oddycha lub } \\
\text { oddycha słabo, niewydolnie }\end{array}$ & $57,8 \%$ & 107 \\
\hline $\begin{array}{c}\text { Gdy jest przytomna i nie oddycha lub } \\
\text { oddycha słabo, niewydolnie }\end{array}$ & $15,7 \%$ & 29 \\
\hline
\end{tabular}




\begin{tabular}{|c|c|c|}
\hline Nie wiem & $5,9 \%$ & 11 \\
\hline
\end{tabular}

Źródło: Opracowanie własne.

Jak wynika z tabeli 4 około 58\% ankietowanych $(57,8 \%)$ prawidłowo wskazało, że RKO należy rozpocząć wtedy, gdy pacjent jest nieprzytomny i nie oddycha lub oddycha słabo/niewydolnie. Nieco ponad $20 \%$ badanych $(20,5 \%)$ wskazało, że należy to zrobić, gdy poszkodowany jest nieprzytomny i prawidłowo oddycha. Około 16\% respondentów $(15,7 \%)$ jest zadania, że resuscytację krążeniowo oddechową należy rozpocząć, gdy osoba jest przytomna i nie oddycha lub oddycha słabo i niewydolnie. Natomiast blisko 6\% $\quad(5,9 \%)$ ankietowanych nie potrafi wskazać, kiedy należy zacząć RKO.

Tabela 5 prezentuje procentowy rozkład odpowiedzi na pytanie dotyczące sposobu sprawdzania oddechu u poszkodowanego.

Tab.5. Opinia respondentów nt. sprawdzania oddechu u poszkodowanego.

\begin{tabular}{|c|c|c|}
\hline \multirow{2}{*}{$\begin{array}{c}|c| \\
\text { 5.Czy wie Pan/Pani jak sprawdzić oddech u } \\
\text { poszkodowanego? }\end{array}$} & $\%$ & $\mathrm{~N}$ \\
\cline { 2 - 3 } & 68 \\
\hline $\begin{array}{c}\text { Zbliżając policzek do ust poszkodowanego i } \\
\text { jednocześnie sprawdzając ruchy klatki } \\
\text { piersiowej przez 10 sekund }\end{array}$ & $36,8 \%$ & 68 \\
\hline $\begin{array}{c}\text { Obserwując ruchy klatki piersiowej i licząc je } \\
\text { przez 1 minutę }\end{array}$ & $36,8 \%$ & 36 \\
\hline $\begin{array}{c}\text { Zbliżając lusterko do ust poszkodowanego i } \\
\text { obserwując osadzającą się parę wodną }\end{array}$ & $19,5 \%$ & 13 \\
\hline Nie wiem & $7 \%$ & \\
\hline
\end{tabular}

Źródło: Opracowanie własne.

Jak wynika z tabeli 5 około $37 \%$ badanych (36,8\%) wskazało prawidłową odpowiedź twierdząc, że oddechy należy sprawdzić poprzez zbliżenie policzka do ust poszkodowanego i jednoczesne 
ocenianie ruchów klatki piersiowej przez 10 sekund. Taki sam odsetek ankietowanych $(36,8 \%)$ jest zdania, że oddechy należy sprawdzić obserwując ruchy klatki piersiowej i licząc je przez 1 minutę. Około $20 \%$ respondentów $(19,5 \%)$ uważa, że należy to robić przykładając lusterko do ust poszkodowanego i obserwując osadzającą się na nim parę wodną. Natomiast $7 \%$ badanych nie potrafi określić sposobu sprawdzania oddechu u poszkodowanego.

W tabeli 6 zaprezentowano procentowy rozkład odpowiedzi na pytanie dotyczące sposobu udrażniania dróg oddechowych.

Tab.6. Opinia respondentów nt. sposobu udrażniania dróg oddechowych.

\begin{tabular}{|c|c|c|}
\hline \multirow[b]{2}{*}{$\begin{array}{l}\text { 6.Czy wie Pan/Pani jak udrożnić u } \\
\text { poszkodowanego drogi oddechowe? }\end{array}$} & \multicolumn{2}{|c|}{ Odpowiedzi } \\
\hline & $\%$ & $\mathrm{~N}$ \\
\hline $\begin{array}{c}\text { Odginając mu głowę do tyłu i unosząc } \\
\text { żuchwę }\end{array}$ & $47,6 \%$ & 88 \\
\hline Przyginając mu głowę do klatki piersiowej & $30,3 \%$ & 56 \\
\hline Otwierając mu szeroko usta & $16,8 \%$ & 31 \\
\hline Nie wiem & $5,4 \%$ & 10 \\
\hline
\end{tabular}

Źródło: Opracowanie własne.

Jak wynika z tabeli 6 blisko 50\% ankietowanych (47,6\%) wskazało prawidłowy sposób udrażniania dróg oddechowych. Natomiast $30,3 \%$ badanych jest zdania, że przygięcie głowy do klatki piersiowej jest właściwym postępowaniem. Z kolei 16,8\% respondentów wskazało otwieranie szeroko ust poszkodowanemu, jako prawidłowe postepowanie przy udrażnianiu dróg oddechowych. Natomiast $5,4 \%$ badanych nie potrafił powiedzieć w jakiś sposób należy udrożnić drogi oddechowe. 
W tabeli 7 przedstawiono procentowy rozkład odpowiedzi na pytanie dotyczące prawidłowej sekwencji uciśnięć klatki piersiowej do liczby oddechów u osoby dorosłej.

Tab.7. Opinia respondentów nt. sekwencji uciśnięć klatki piersiowej do oddechów.

\begin{tabular}{|c|c|c|}
\hline & \multicolumn{2}{|c|}{ Odpowiedzi } \\
\cline { 2 - 3 } $\begin{array}{c}\text { 7. Czy wie Pan/Pani jaka jest prawidłowa } \\
\text { sekwencja uciśnięć klatki piersiowej do } \\
\text { liczby oddechów u osoby dorosłej? }\end{array}$ & $\%$ & $\mathrm{~N}$ \\
\hline $30: 2$ & & \\
\hline $15: 1$ & $62,2 \%$ & 115 \\
\hline $40: 4$ & $20 \%$ & 37 \\
\hline Nie wiem & $13,5 \%$ & 25 \\
\hline
\end{tabular}

Źródło: Opracowanie własne.

Jak wynika z tabeli 7 zdecydowania większość respondentów $(62,2 \%)$ wskazała prawidłową sekwencję uciśnięć klatki piersiowej do oddechów tj. 30:2. Natomiast 20\% badanych jest zdania, że prawidłową sekwencją jest stosunek 15:2, natomiast $13,5 \%$ ankietowanych uważa, że 40:4. Zaś 4,3\% respondentów nie potrafi wskazać poprawnej odpowiedzi.

W tabeli 8 zaprezentowano procentowy rozkład odpowiedzi na pytanie dotyczące opinii, czy w resuscytacji krążeniowo-oddechowej wykonywanej przez jedną osobę można ograniczyć się tylko do wykonywania uciśnięć klatki piersiowej.

Tab.8. Opinia respondentów nt. ograniczenia RKO do uciśnięć.

\begin{tabular}{|c|c|c|}
\hline \multirow{2}{*}{$\begin{array}{c}\text { 8.Czy według Pana/Pani opinii w resuscytacji } \\
\text { krążeniowo-oddechowej wykonywanej przez }\end{array}$} & \multicolumn{2}{|c|}{ Odpowiedzi } \\
$\begin{array}{c}\text { jedną osobę można ograniczyć się tylko do } \\
\text { wykonywania uciśnięć klatki piersiowej? }\end{array}$ & $\%$ & $\mathrm{~N}$ \\
\hline
\end{tabular}




\begin{tabular}{|c|c|c|}
\hline Tak & $45,4 \%$ & 84 \\
\hline Nie & $39,5 \%$ & 73 \\
\hline Nie wiem & $15,1 \%$ & 28 \\
\hline
\end{tabular}

Źródło: Opracowanie własne.

Jak wynika z tabeli 8 około $45 \%$ badanych $(45,4 \%)$ uważa, że w przypadku kiedy jedna osoba wykonuje resuscytację oddechowo - krążeniową, można ją ograniczyć tylko do uciśnięć klatki piersiowej. Niespełna $40 \%$ ankietowanych $(39,5 \%)$ jest zadania, że nie można pominąć wdechów i należy wykonać pełne RKO. Natomiast nieco ponad 15\% respondentów (15,1\%) nie potrafiło wskazać jednoznacznej odpowiedzi.

W tabeli 9 przedstawiono procentowy rozkład odpowiedzi na pytanie dotyczące wskazania prawidłowego miejsca ucisku klatki piersiowej.

Tab.9. Opinia respondentów nt. miejsca uciśnięć klatki piersiowej.

\begin{tabular}{|c|c|c|}
\hline & \multicolumn{2}{|c|}{ Odpowiedzi } \\
\cline { 2 - 3 } $\begin{array}{c}\text { 9. Czy wie Pan/Pani jakie jest prawidłowe } \\
\text { miejsce do ucisku klatki piersiowej? }\end{array}$ & $\%$ & $\mathrm{~N}$ \\
\hline Środek klatki piersiowej na mostku & $38,4 \%$ & 71 \\
\hline Lewa strona klatki piersiowej & $29,2 \%$ & 54 \\
\hline Dolny koniec mostka & $24,3 \%$ & 45 \\
\hline Nie wiem & $8,1 \%$ & 15 \\
\hline
\end{tabular}

Źródło: Opracowanie własne.

Jak wynika z tabeli 9 niespełna 40\% ankietowanych (38,4\%) za prawidłowe miejsce uznało środek klatki piersiowej. Około $30 \%$ respondentów $(29,2 \%)$ jest zdania, że właściwym miejscem ucisku klatki piersiowej jest jej lewa strona. Według 24,3\% badanych dolny 
koniec mostka jest tym odpowiednim miejscem. Natomiast 8,1\% ankietowanych nie potrafiło wskazać jednoznacznej odpowiedzi.

Tabela 10 przedstawia procentowy rozkład odpowiedzi na pytanie dotyczące użycia automatycznego defibrylatora AED (Automated External Defibrillator).

Tab.10. Opinia respondentów nt. czasu użycia AED.

\begin{tabular}{|c|c|c|}
\hline \multirow{2}{*}{$\begin{array}{c}\text { 10.Czy wie Pan/ Pani kiedy należy użyć } \\
\text { automatycznego defibrylatora zewnętrznego } \\
\text { AED u osoby poszkodowanej? }\end{array}$} & $\%$ & $\mathrm{~N}$ \\
\cline { 2 - 3 } & $\%$ Odpowiedzi \\
\hline Gdy jest nieprzytomna i prawidłowo oddycha & $13,5 \%$ & 25 \\
\hline $\begin{array}{c}\text { Gdy jest nieprzytomna i nie oddycha lub } \\
\text { oddycha słabo, niewydolnie }\end{array}$ & $58,9 \%$ & 109 \\
\hline $\begin{array}{c}\text { Gdy jest przytomna i nie oddycha lub } \\
\text { oddycha słabo, niewydolnie }\end{array}$ & $18,9 \%$ & 35 \\
\hline Nie wiem & $8,6 \%$ & 16 \\
\hline
\end{tabular}

Źródło: Opracowanie własne.

Jak wynika $\mathrm{z}$ tabeli 10 około $60 \%$ badanych (58,9\%) prawidłowo wskazało, że automatycznego defibrylatora należy użyć wtedy kiedy osoba poszkodowana jest nieprzytomna i nie oddycha lub oddycha słabo i niewydolnie. Około $19 \%$ ankietowanych $(18,9 \%)$ jest zdania, że AED należy użyć wtedy, gdy poszkodowany jest przytomny i nie oddycha lub oddycha słabo i niewydolnie. Nieco ponad $13 \%$ respondentów (13,5\%) uważa, że odpowiednim momentem, kiedy należy wykorzystać AED jest sytuacja, kiedy osoba jest nieprzytomna, ale oddycha prawidłowo. Niespełna $9 \%$ badanych $(8,6 \%)$ nie potrafiło jednoznacznie określić kiedy należy użyć automatycznego defibrylatora AED.

Tabela 11 przedstawia procentowy rozkład odpowiedzi na pytanie dotyczące sposobu szukania i miejsca przechowywania automatycznego defibrylatora AED. 
Tab.11. Opinia respondentów nt. sposobu szukania AED.

\begin{tabular}{|c|c|c|}
\hline \multirow{2}{*}{$\begin{array}{c}\text { 11.Czy wie Pan/Panie gdzie i jak szukać } \\
\text { automatycznego defibrylatora AED? }\end{array}$} & $\%$ & $\mathrm{~N}$ \\
\cline { 2 - 3 } & & \\
\hline $\begin{array}{c}\text { Za pomocą aplikacji „Ratuj z sercem” oraz } \\
\text { szukając naklejki z oznaczeniem AED }\end{array}$ & $41,6 \%$ & 77 \\
\hline W instytucjach użytku publicznego & $44,9 \%$ & 83 \\
\hline Nie wiem & $13,5 \%$ & 25 \\
\hline
\end{tabular}

Źródło: Opracowanie własne.

Jak wynika z tabeli 11 około 42\% badanych (41,6\%) wiedziało, że automatyczny defibrylator AED należy odnaleźć za pomocą aplikacji „Ratuj z sercem” oraz szukając naklejki z oznaczeniem AED. Niespełna $45 \%$ ankietowanych (44,9\%) poszukiwałoby defibrylatora w instytucjach użytku publicznego, zaś 13,5\% nie potrafi określić, w jaki sposób i gdzie szukałoby AED.

W tabeli 12 zaprezentowano procentowy rozkład odpowiedzi na pytanie dotyczące sposobu ułożenia poszkodowanego w pozycji bezpiecznej.

Tab.12. Opinia respondentów nt. ułożenia poszkodowanego w pozycji bezpiecznej.

\begin{tabular}{|c|c|c|}
\hline \multirow{2}{*}{$\begin{array}{c}\text { 12. Czy wie Pan/Pani jak wygląda ułożenie } \\
\text { osoby poszkodowanej w pozycji bezpiecznej? }\end{array}$} & $\%$ & $\mathrm{~N}$ \\
\cline { 2 - 3 } & $\%$ Odpowiedzi \\
\hline $\begin{array}{c}\text { Ułożenie poszkodowanego na brzuchu z } \\
\text { głową odwróconą na bok }\end{array}$ & $15,1 \%$ & 28 \\
\hline $\begin{array}{c}\text { Ułożenie poszkodowanego z nogami } \\
\text { uniesionymi do góry }\end{array}$ & $25,4 \%$ & 47 \\
\hline $\begin{array}{c}\text { Ułożenie poszkodowanego na boku z głową } \\
\text { odchyloną do tyłu }\end{array}$ & $49,2 \%$ & 91 \\
\hline Nie wiem & $10,3 \%$ & 19 \\
\hline
\end{tabular}

Źródło: Opracowanie własne. 
Jak wynika z tabeli 12 zdecydowana większość (49,2\%) respondentów wskazała prawidłowe ułożenie poszkodowanego tj. ułożenie na boku $\mathrm{z}$ odchyloną głową. $\mathrm{Z}$ kolei $25,4 \%$ badanych ułożyłoby poszkodowanego $\mathrm{z}$ nogami do góry. Natomiast 15,1\% ankietowanych zabezpieczyłoby pacjenta poprzez położenie go na brzuchu z głową odwróconą na bok. Z kolei 10,3\% badanych nie potrafiło wskazać prawidłowej odpowiedzi.

W tabeli 13 przedstawiono procentowy rozkład odpowiedzi na pytanie dotyczące znajomości etapów udzielania pierwszej pomocy.

Tab.13. Opinia respondentów nt. etapów pierwszej pomocy.

\begin{tabular}{|c|c|c|}
\hline \multirow{2}{*}{$\begin{array}{c}\text { 13. Czy wie Pan/Pani jaki jest pierwszy etap } \\
\text { udzielania pierwszej pomocy j? }\end{array}$} & $\%$ & $\mathrm{~N}$ \\
\cline { 2 - 3 } & & \\
\hline $\begin{array}{c}\text { Ocena sytuacji i zabezpieczenie miejsca } \\
\text { wydarzenia }\end{array}$ & $38,8 \%$ & 72 \\
\hline Telefon pod numer alarmowy & $31,9 \%$ & 59 \\
\hline $\begin{array}{c}\text { Podjęcie resuscytacji krążeniowo- } \\
\text { oddechowej }\end{array}$ & $22,2 \%$ & 41 \\
\hline Nie wiem & $13 \%$ & 7 \\
\hline
\end{tabular}

Źródło: Opracowanie własne.

Jak wynika z tabeli 13 około 39\% badanych $(38,8 \%)$ wskazało prawidłowo pierwszy etap łańcucha życia jako ocenę sytuacji i zabezpieczenia miejsca wydarzenia. Niespełna $32 \%$ ankietowanych $(31,9 \%)$ jest zdania, że najpierw należy wykonać telefon pod numer alarmowy, a $22,2 \%$ respondentów jest zdania, że trzeba wtedy podjąć RKO. Z kolei $13 \%$ badanych nie potrafi wskazać pierwszego etapu udzielania pierwszej pomocy przedmedycznej. 
Tabela 14 przedstawia procentowy rozkład odpowiedzi na pytanie dotyczące znajomości numeru alarmowego.

Tab.14. Opinia respondentów nt. znajomości numeru alarmowego.

\begin{tabular}{|c|c|c|}
\hline \multirow{2}{*}{$\begin{array}{c}\text { 14. Czy wie Pan/Pani jaki jest numer } \\
\text { alarmowy? }\end{array}$} & \multicolumn{2}{|c|}{ Odpowiedzi } \\
\cline { 2 - 3 } & $\%$ & $\mathrm{~N}$ \\
\hline 999 lub 112 & & \\
\hline 998 & $44,9 \%$ & 83 \\
\hline 997 & $22,7 \%$ & 42 \\
\hline Nie wiem & $24,9 \%$ & 46 \\
\hline
\end{tabular}

Źródło: Opracowanie własne.

Jak wynika z tabeli 14 niespełna 45\% ankietowanych (44,9\%) prawidłowo wskazało numer alarmowy (999 lub 112). Około $24 \%$ badanych $(24,9 \%)$ wskazało na numer 997 , natomiast niespełna $23 \%$ respondentów $(22,7 \%)$ podało numer 998 . Zaś blisko $8 \%$ ankietowanych $(7,6 \%)$, nie wiedziało jaki jest numer alarmowy.

Tabela 15 przedstawia procentowy rozkład odpowiedzi na pytanie dotyczące wiedz kto ma obowiązek prawny udzielania pierwszej pomocy. 
Tab.15.0pinia respondentów nt. obowiązku prawnego względem udzielania pierwszej pomocy.

\begin{tabular}{|c|c|c|}
\hline \multirow{2}{*}{$\begin{array}{c}\text { 15. Czy wie Pan/Pani kto ma prawny } \\
\text { obowiązek udzielania pierwszej pomocy? }\end{array}$} & $\%$ & $\mathrm{~N}$ \\
\cline { 2 - 3 } & & 109 \\
\hline Każdy obywatel & $58,9 \%$ & 37 \\
\hline $\begin{array}{c}\text { Każdy obywatel po kursie, szkoleniu lub z } \\
\text { wykształcenie medycznym }\end{array}$ & $20 \%$ & 25 \\
\hline Tylko osoby z wykształceniem medycznym & $13,5 \%$ & 14 \\
\hline Nie wiem & $7,6 \%$ & \\
\hline
\end{tabular}

Źródło: Opracowanie własne.

Jak wynika z tabeli 14 niecałe $60 \%$ ankietowanych $(28,9 \%)$ jest zdania, że każdy obywatel ma obowiązek udzielania pierwszej pomocy. Zaś $20 \%$ badanych twierdzi, że leży to w gestii osób po kursie, szkoleniu lub $\mathrm{z}$ wykształceniem medycznym. Niespełna $14 \%$ respondentów $(13,5 \%)$ jest zdania, że pierwszej pomocy mogą udzielać tylko osoby z wykształceniem medycznym. Natomiast $7,6 \%$ badanych nie wie, kto jest objęty obowiązkiem udzielania pierwszej pomocy

\section{Dyskusja}

Posiadanie wiedzy medycznej i jej adekwatne wykorzystywanie w praktyce jest niezmiernie ważnym elementem egzystencji społeczeństwa. Świadek zdarzenia może zareagować odpowiednio szybko, dając tym samym szanse na przeżycie drugiemu człowiekowi. Ważnym aspektem jest edukacja społeczeństwa nt. udzielania pierwszej pomocy począwszy od dzieciństwa. Prowadzona jest ona m.in. przez pracowników systemu ochrony zdrowia, na których także spoczywa rola edukatorów w powyższym zakresie[6]. 
W badaniach własnych mniej niż połowa respondentów określa swoją wiedzę na temat udzielania pomocy przedmedycznej jako umiarkowaną oraz wskazuje, że czerpie ją głównie z zajęć, szkoleń i kursów. Większość ankietowanych potwierdziło, że każdy obywatel ma obowiązek udzielania pierwszej pomocy. Niemniej jednak znaczny odsetek badanych nie podjąłby takich działań. Ponad połowa respondentów prawidłowo wskazuje moment rozpoczęcia resuscytacji krążeniowo - oddechowej. Natomiast większość badanych nie potrafiła: prawidłowo określić zasady sprawdzania oddechu u poszkodowanego czy udrażniania dróg oddechowych, wskazać miejsce uciśnięć klatki piersiowej, potwierdzić, że pierwszym etapem udzielania pierwszej pomocy jest ocena sytuacji i zabezpieczenie miejsca wydarzenia.

Analiza badań własnych jednoznacznie wskazuje, że wiedza, którą posiadają studenci nt. udzielania pierwszej pomocy jest niewystarczająca. Podobnego zdania są respondenci bowiem tylko $12,5 \%$ ankietowanych uważa, że poziom wiedzy jaki reprezentuje jest bardzo dobry. Natomiast około $5 \%$ badanych twierdzi, że jest on zły. W badaniach Blichniarz odsetek osób bardzo dobrze oceniających swoją wiedzę nt. pierwszej pomocy jest zbliżony (12\%)[7].

Przeprowadzone badanie pozwoliło stwierdzić, że studenci PWSZ we Włocławku dysponują niewystarczającą wiedzą nt. prawidłowego stosunku uciśnięć klatki piersiowej do oddechów. Takiej odpowiedzi udzieliło około $62 \%$ ankietowanych. Natomiast w badaniu Wojczyk prawidłowo odpowiedziało na to pytanie $96 \%$ badanych[8].

Zarówno badania własne jak i Czyż wykazały, że znaczny odsetek respondentów wykazuje lęk przed udzieleniem pierwszej pomocy przedmedycznej, wynikający najczęściej z niedostatecznej i nieusystematyzowanej wiedzy[9].

Uzyskane wyniki badań własnych, a także innych badaczy jasno pokazują, że użycie automatycznego defibrylatora AED sprawia problem, tak samo jak określenie, gdzie może się on znajdować[9]. 
W badaniach Blichniarz ponad połowa ankietowanych jest zdania, że ułożenie poszkodowanego w pozycji bezpiecznej polega na ułożeniu go bokiem, z dłonią prawą pod policzkiem, głową odchyloną lekko do tyłu oraz nogą prawą zgiętą w kolanie. $W$ badaniach własnych tego samego zdania jest niespełna 49\% respondentów[7].

\section{Wnioski}

Studenci prezentują umiarkowany poziom wiedzy w zakresie udzielania pierwszej pomocy. Niezbędne są systematyczne działania edukacyjne $\mathrm{w}$ zakresie ich przygotowania do świadomego, odpowiedzialnego udziału w ratowaniu życia drugiego człowieka

\section{Zalecenia dla praktyki pielęgniarskiej}

Propagowanie idei uczestnictwa w kursach udzielania pierwszej oraz poszerzania wiedzy na temat udzielania pierwszej pomocy przedmedycznej to zadanie, w którym aktywny udział powinny brać pielęgniarki, jako członkowie interdyscyplinarnego zespołu terapeutycznego.

\section{Bibliografia/Bibliography:}

1. Obwieszczenie Marszałka Sejmu Rzeczypospolitej Polskiej z dnia 25 kwietnia 2019 r. w sprawie ogłoszenia jednolitego tekstu ustawy o Państwowym Ratownictwie Medycznym (Dz.U.2019 poz.993)

2. Ustawa o Państwowym Ratownictwie Medycznym z dnia 8 września 2006 r. ( Dz.U. z 2006r. Nr 191,poz 1410).

3. https://www.gov.pl/web/zdrowie/pierwsza-pomoc (dostęp 16.07.2019).

4. Kodeks Karny ( Dz.U. z 1997 r. Nr 88, poz. 553 z póżn. zm.)

5. Gucwa J., Ostrowski M. Zaawansowane zabiegi resuscytacyjne i wybrane stany nagłe. Medycyna Praktyczna, Kraków 2018;41-43. 
6. Olejniczak D., Miciuk D., Religioni U. Ocena stanu wiedzy studentów Warszawskiego Uniwersytetu Medycznego na kierunku pielęgniarstwo na temat udzielania pierwszej pomocy przedmedycznej. Piel. Zdr. Publ. 2013;3,2:101-110.

7. Blichniarz M., Biernacka B. Poziom wiedzy społeczeństwa na temat udzielania pierwszej pomocy przedmedycznej. Aspekty zdrowia i choroby. 2016;I,2:39-49.

8. Wojczyk A. Stan wiedzy studentów pielęgniarstwa na temat resuscytacji krążeniowo - oddechowej. Puls Uczelni. 2015;9,2:7-11.

9. Czyż R., Kwiatoń M., Górniak I. Ocena poziomu wiedzy studentów wybranych polskich uczelni wyższych na temat zasad udzielania pierwszej pomocy osobie dorosłej $w$ stanach nagłych. Juranal of Education, Health and Sport.2016,6(7):399-410.

Otrzymano: 17.07.2019r.

Zaakceptowano: 01.09.2019r. 
